\title{
Treatment of ANCA - Associated Vasculitis
}

\author{
Christina G. Katsiari and Lazaros Sakkas \\ Department of Rheumatology, School of Medicine, University of Thessaly, Larissa,
}

Greece

\section{Introduction}

ANCA - associated vasculitis (AAV) encompass Wegener granulomatosus (WG), Churg Strauss syndrome (CSS) and Microscopic Polyangiitis (MPA). Granuloma formation characterizes both WG and CSS, while necrotising inflammation of middle to small arteries, pauci-immune glomerulonephritis and production of ANCA typify all three of them. Common clinical and laboratory features point towards common pathogenetic mechanisms and thus therapeutic approach have evolved over the years from treatment of individual members of the group to unified treatment strategies. It is the presentation of the disease rather than a particular AAV that guides treatment decisions. Clinical subtypes of AAV according to the extend and the severity of the disease, have been proposed by the European Vasculitis Study (EUVAS) Group (Jayne \& Rasmussen 1997) (Table 1): AAV can be presented as localized, early systemic, generalized, severe or refractory disease. This classification currently serves as the basis for the assignment of different treatment regimens.

Forty years ago AAV was a rapidly fatal disease. One-year survival was estimated to be less than $20 \%$, mainly due to pulmonary and/or renal failure and steroids-related infection (Hoffman et al. 1992). The introduction of oral cyclophosphamide (CyP) during the '70s radically changed the prognosis of AAV. Recent data from the EUVAS Group trials show that survival at 1-year is currently almost $90 \%$. CyP in combination with prednisone remain today the cornerstone of treatment of AAV. However, several issues have emerged: a) there are still patients that either die early in the course of the disease or display progressive disease refractory to conventional treatment, b) relapses are frequent, affecting approximately $50 \%$ of patients with AAV during extended follow-up, c) the burden of drugrelated toxicity is high, as serious adverse events affect approximately $40 \%$ of the patients. In addition to glucocorticoids toxicity, $\mathrm{CyP}$ can acutely lead to cytopenias, hemorrhagic cystitis and infections along with late complications including gonadal insufficiency and infertility, myelodysplasias and bladder cancer.

In an effort to minimize CyP toxicity as well as to find regimens that could replace CyP in cases of non-responding, refractory, or relapsing disease, several treatment options have been considered. During the last 20 years and despite the rarity of AAV, several multicenter, multi-national randomized control trials (RCTs) were conducted largely due to the combined efforts of EUVAS Group and the VCRC (Vasculitis Clinical Research Consortium), which have altered our treatment practice as it will be discussed below. Treatment of AAV consists of an initial phase aiming at rapid induction of remission and a second phase where maintenance of remission is sought. 


\begin{tabular}{|c|c|}
\hline AAV Subtype & Description \\
\hline Localized & $\begin{array}{l}\text { one system, } \\
\text { typically the upper respiratory track in WG }\end{array}$ \\
\hline Early Systemic & $\begin{array}{l}\text { involvement of multiple sites but without } \\
\text { impending renal or other vital organ failure }\end{array}$ \\
\hline Generalized & $\begin{array}{l}\text { impending vital organ failure or renal involvement } \\
\text { with creatinine level below } 5.6 \mathrm{mg} / \mathrm{dL}(500 \mu \mathrm{mol} / \mathrm{L})\end{array}$ \\
\hline Severe & $\begin{array}{l}\text { vital organ failure, typically renal involvement with } \\
\text { serum creatinine over } 5.6 \mathrm{mg} / \mathrm{dL}(500 \mu \mathrm{mol} / \mathrm{L})\end{array}$ \\
\hline Refractory & progressive disease despite conventional treatment \\
\hline
\end{tabular}

Table 1. Clinical Subtypes of AAV according to the extend and the severity of the disease

\section{Induction of remission}

The gold standard for induction of remission in most cases of AAV has been the combination of high dose prednisolone $(1 \mathrm{mg} / \mathrm{kg} /$ day with or without previous pulses $1 \mathrm{~g} / \mathrm{d}$ $x 3 \mathrm{~d})$ with CyP either orally $(2 \mathrm{mg} / \mathrm{kg} /$ day $)$ or intravenously $\left(0.75 \mathrm{~g} / \mathrm{m}^{2}\right.$ every month for 6 months) (Adu et al. 1997; Guillevin et al. 1997). In order to reduce the cumulative dose of drugs and thus adverse effects, current treatment strategies are differentiated according to the presentation of the disease (Table 1) and along with different schemes of СyP administration include several other medications such as rituximab, mycophenolate mofetil (MMF) and methotrexate (MTX).

\subsection{Generalized AAV}

Generalized AAV refers to patients who display imminent vital organ failure or renal involvement with creatinine level below $5.6 \mathrm{mg} / \mathrm{dL}(500 \mu \mathrm{mol} / \mathrm{L})$.

In an earlier study including 47 patients with generalized AAV and renal involvement intravenous pulses of $\mathrm{CyP}\left(0.75 \mathrm{~g} / \mathrm{m}^{2}\right.$, monthly for 6 months) were equally effective in achieving remission as oral CyP. Moreover, fewer incidents of cytopenia and infections had been recorded in the pulse group (Haubitz \& Schellong 1998).

A randomized controlled trial by EUVAS, termed CYCLOPS, compared another scheme of pulse cyclophosphamide with daily oral cyclophosphamide for the induction of remission of AAV (De Groot et al. 2009). Patients with generalized AAV $(n=149)$ and renal involvement received prednisolone plus either pulse cyclophosphamide $(15 \mathrm{mg} / \mathrm{kg}$ every 2-3 weeks; $\mathrm{n}=76$ ) or daily oral cyclophosphamide $(2 \mathrm{mg} / \mathrm{kg}$ per day; $\mathrm{n}=73)$. The efficacy of both regimens was similar in inducing remission. Lower cumulative dose of $\mathrm{CyP}$ was achieved in the pulse group, which displayed fewer episodes of leukopenia. It should be noted though that following pulse treatment there was a tendency towards a higher rate of relapse compared to oral treatment during the 9-month follow-up of the study.

Although it is not clear whether there are significant differences regarding efficacy and safety between the 2 schemes of $\mathrm{CyP}$ pulses, EULAR recommendations endorse the following strategy (Mukhtyar et al. 2009): administration of 15mg/ kg of CyP every 2 weeks for 3 pulses and then every 3 weeks for additional 3-6 pulses. According to the same set of recommendations prednisolone intake should start at $1 \mathrm{mg} / \mathrm{kg} /$ day (or $60 \mathrm{mg} /$ day) for 1 month, tapered to $15 \mathrm{mg}$ / day at 3 months and $7.5 \mathrm{mg} /$ day at 12 months. 
Following the paradigm of lupus nephritis, MMF has been examined whether it can replace $\mathrm{CyP}$ for the induction of remission in AAV. In a study including 35 patients with AAV renal vasculitis with serum creatinine $<5.6 \mathrm{mg} / \mathrm{dL}, 18$ received MMF (2g/day) and 17 monthly pulses of CyP $\left(0.75-1.0 \mathrm{~g} / \mathrm{m}^{2}\right)$ for 6 months (Hu et al. 2008). According to the study, complete remission was achieved in $78 \%$ in the MMF group compared to $47 \%$ in the CyP group. Whether MMF truly bears superiority towards CyP remains to be verified in large controlled trilas. MYCYC (http://clinicaltrials.gov/ct2/show/ NCT00414128 (2010)), a multi-center controlled trial by EUVAS comparing the efficacy of MMF and CyP has been initiated. Notably, MMF will be used at the increased dose of $3 \mathrm{~g} /$ day.

Rituximab, an anti-CD20 chimeric monoclonal antibody that effectively depletes B cells, has recently received much attention regarding its treatment potential in AAV. The number of activated B cells in AAV is associated with disease activity and the extend of organ involvement. Moreover, B cells generate ANCA-producing plasma cells. Studies in humans and animal models support the concept that ANCA have a central role in the pathogenesis and maintenance of AAV (Xiao et al. 2002)

The efficacy of rituximab to induce remission in generalized AAV was examined in two RCTs. In RITUXVAS trial (Jones et al. 2010), 11 patients received pulses CyP plus glucocorticoids and 33 patients additionally received rituximab. The rituximab group received four infusions of rituximab $375 \mathrm{mg} / \mathrm{m}^{2}$ per week plus two infusions of intravenous cyclophosphamide $15 \mathrm{mg} / \mathrm{kg}$. The cyclophosphamide group received between six and ten infusions of cyclophosphamide $15 \mathrm{mg} / \mathrm{kg}$. Azathioprine was used as maintenance therapy in all patients. At 12 months, remission rates were comparable between the two groups (76\% for rituximab and $82 \%$ for CyP group). Rituximab $\left(375 \mathrm{mg} / \mathrm{m}^{2}\right.$ per week for four weeks) was also compared with oral CyP (2 mg/ $\mathrm{kg}$ per day) in addition to glucocorticoids in the RAVE trial (Stone et al. 2010). At 6 months remission rates were $64 \%$ for the rituximab and $53 \%$ for the $\mathrm{CyP}$ group. These lower rates of remission compared to other studies were probably due to the aggressive tapering of corticosteroids employed.

Overall, both studies show that rituximab therapy is not inferior to $\mathrm{CyP}$ (oral or pulses) treatment for the induction of remission in patients with generilized AAV. It should be noted, however, that adverse effects were also comparable between rituximab and CyP receivers an issue that has to be further addressed in studies with extended follow-up. Rituximab can thus replace $\mathrm{CyP}$ treatment especially in patients where $\mathrm{CyP}$ is contraindicated and could be the drug of choice in patients with childbearing potential. In spring of 2011, rituximab became the first drug to get an FDA approval for the treatment of AAV.

\subsection{Early systemic AAV}

Early systemic AAV refers to patients with involvement of multiple sites but without imminent renal or other vital organ failure.

Following initial open label studies with promising results, the NORAM study (De Groot et al. 2005), a RCT initiated by EUVAS, evaluated the efficacy of MTX as a potentially less toxic than $\mathrm{CyP}$ alternative to induce remission in patients with early systemic AAV. In addition to corticosteroids, patients received either oral CyP $(2 \mathrm{mg} / \mathrm{Kg}$ per day) or oral MTX (initial dose $15 \mathrm{mg}$ / week that was increased to $20-25 \mathrm{mg} /$ week) for 12 months. Patients' follow-up lasted 18 months, and during the last 6 months all medications were stopped. At 12 months remission rates between the two groups were comparable $(89.8 \%$ for MTX and $93.5 \%$ for oral $\mathrm{CyP}$ ). Time to remission in overall was also comparable. However, some patients with 
pulmonary involvement or relatively extensive disease in the MTX group had delayed onset of remission. In addition, at 18 months the relapse rate in the MTX group was $69.5 \%$, which was significantly higher compared to that observed in the CyP group (46.5\%). These high relapse rates in both treatment arms suggest that treatment of early systemic AAV should last beyond 1 year. The overall frequency of adverse events did not differ between the two groups. Leukopenia was prevalent with the use of $\mathrm{CyP}$ as was liver dysfunction with the use of MTX. In view of the results of the NORAM study, EULAR recommend MTX as an alternative to $\mathrm{CyP}$ for remission induction in non-organ-threatening or non-life threatening AAV.

\subsection{Severe AAV}

Severe AAV refers to patients with vital organ failure, typically renal involvement with serum creatinine over $5.6 \mathrm{mg} / \mathrm{dL}(500 \mu \mathrm{mol} / \mathrm{L})$.

Patients with life- and/or vital organ threatening manifestations, such as diffuse alveolar hemorrhage $(\mathrm{DAH})$, severe rapidly progressive glomerulonephritis (serum creatinine $>5.6$ $\mathrm{mg} / \mathrm{dL}$ ), glomerulonephritis with double serum positivity for MPO-ANCA and antiglomerular basement membrane antibodies (Rutgers et al. 2005), require urgent, aggressive treatment. Supportive measures such as blood transfusion and mechanical ventilation or hemodialysis are frequently required.

In a EUVAS trial called MEPEX (Jayne et al. 2007) the effectiveness of plasma exchange was evaluated in patients with severe AAV involving acute renal failure. All 137 patients received oral $\mathrm{CyP}$ and prednisolone. One group was assigned to additionally receive three infusions of $1 \mathrm{~g}$ methylprednisolone pulse therapy $(n=67)$ and a second to receive seven courses of plasma exchanges $(n=70)$. At 3 months, $69 \%$ of patients who received plasma exchanges were alive and dialysis independent compared to the significantly lower $49 \%$ of patients treated with methylprednisolone pulses.

The usefulness of plasma exchange in patients already on dialysis at the time of diagnosis has also been suggested (de Lind et al. 2007). Intravenous pulses methylprednisolone as adjunctive therapy in patients with severe tubular atrophy and $<18 \%$ normal glomeruli increased the chance of therapy-related death over the chance of dialysis independence. The same was true for the group receiving plasma exchange only when the proportion of normal glomeruli reached a value of $<2 \%$.

Although there are no RCT available, plasma exchanges appear to be warranted in patients with DAH. In a retrospective review of 20 patients with DAH that were presented at a single institute and were treated with plasma exchanges in addition to intravenous methylprednisolone with or without $\mathrm{CyP}$, resolution of lung hemorrhage was achieved in all 20 patients after an average number of 6.4 treatments. Historical review of 11 patients hospitalized at the same centre and did not receive plasma exchanges revealed 3 deaths. (Klemmer Am J Kid Dis 2003).

\subsection{Other treatments}

Anti-Tumor Necrosis Factor (anti-TNF) regimens have been considered as an alternative to current treatment for over a decade. Based on the beneficial effects of TNF blockade in other chronic inflammatory disorders and the fact that several lines of evidence implicate TNF in the pathogenesis of AAV in humans and animal models of the disease, several small pilot 
studies evaluated the therapeutic potential of infliximab revealing promising results. However, data derived from subsequent studies were conflicting and could not corroborate any additional benefit from the use of infliximab in patients with AAV (Booth et al. 2004; Josselin et al. 2008; Morgan et al. 2010). It should be noted that there is no RCT for infliximab in AAV. On the contrary, the effect of entanercept, another anti-TNF agent, was examined in a large RCT (WGET) with patients suffering from WG (Wegener's G.E.T.W. 2005). In WGET, etanercept was used as an additional therapy to standard treatment for the induction and maintenance of remission in 180 patients with WG. At 27 months, remission rates and timeto-remission, were not significantly different between the two groups. It should be emphasized that six patients in the etanercept group developed solid cancers compared to no such malignancies in the control group (Stone et al. 2006). Hence, etanercept is considered ineffective and potentially hazardous when added to standard therapy for induction and maintenance of remission in WG. The overall experience with anti-TNF drugs in AAV is either negative or inconclusive. Skepticism has replaced initial enthusiasm and currently the use of TNF blockade in patients with AAV appears remote.

\begin{tabular}{|c|c|c|}
\hline Drug & Dosage & Comments \\
\hline Prednisolone & $\begin{array}{l}60 \mathrm{mg} / \text { day for } 1 \text { month } \\
\text { tapered to } 15 \mathrm{mg} / \text { day at } 3 \\
\text { months }\end{array}$ & $\begin{array}{l}\text { Use IV methylprednisolone } 500-1,000 \\
\mathrm{mg} / \text { day for } 3 \text { days in critical organ } \\
\text { manifestations }\end{array}$ \\
\hline $\begin{array}{l}\text { Cyclophosphamide } \\
\text { IV pulse }\end{array}$ & $\begin{array}{l}15 \mathrm{mg} / \mathrm{Kg} \text { 2-weekly for } 3 \\
\text { pulses, then 3-weekly for 3-6 } \\
\text { pulses }\end{array}$ & $\begin{array}{l}\text { Oral cyclophosphamide ( } 2 \\
\mathrm{mg} / \mathrm{Kg} / \text { day) might be used adjusted } \\
\text { to keep } \mathrm{WBC}>3,000 / \mu \mathrm{L}\end{array}$ \\
\hline Methotrexate & $\begin{array}{l}\text { Starting dose } 15 \mathrm{mg} / \text { week, } \\
\text { increased to } 20-25 \mathrm{mg} / \text { week } \\
\text { at } 2 \text { months }\end{array}$ & $\begin{array}{l}\text { Use in non critical organ manifestations } \\
\text { (normal serum creatinine) }\end{array}$ \\
\hline Rituximab IV & $\begin{array}{l}375 \mathrm{mg} / \mathrm{m} 2 / \text { week for } 4 \\
\text { pulses }\end{array}$ & $\begin{array}{l}\text { Use in intolerance to } \mathrm{CyP} \text { and in young } \\
\text { patients with non-severe critical organ } \\
\text { manifestations }\end{array}$ \\
\hline $\begin{array}{l}\text { Mycophenolate } \\
\text { Mofetil }\end{array}$ & 2 g/day & $\begin{array}{l}\text { In patients with moderate renal } \\
\text { involvement who cannot take } \\
\text { cyclophosphamide }\end{array}$ \\
\hline Plasmapheresis & & $\begin{array}{l}\text { Use in critical organ manifestations } \\
\text { (serum creatinine }>5.6 \mathrm{mg} / \mathrm{dL} \text {, lung } \\
\text { hemorrhage) }\end{array}$ \\
\hline
\end{tabular}

Table 2. Induction of remission in ANCA-associated vasculitis 
Since ANCA may have a central role in the pathogenesis of AAV, the idea to target autoreactive T cells that drive the production of ANCA excreeting-plasma cells appears to be a logical treatment approach. Abatacept, a CTLA4-Ig molecule, blocks the costimulatory talk between $\mathrm{T}$ and $\mathrm{B}$ cells and has been proven efficacious in the treatment of rheumatoid arthritis. A RCT to evaluate relapse rate over a 24 month period in patients treated for 12 months with abatacept in addition to standard treatment (MTX plus prednisone) had been initiated but unfortunately was recently terminated due to slow recruitment (ABAVAS Study NCT00482066).

Recent data generated increased interest towards the role of the complement pathway in the pathogenesis of AAV, which appears to have an essential role on how ANCA can damage the vascular wall. Eculizumab is a monoclonal antibody that blocks the activation of $\mathrm{C} 5$, a central component of the complement cascade. Blockade of C5 activation was shown to have substantial therapeutic effect in animal models of AAV. A similar approach to treat patients with AAV will be evaluated in a pilot study with 10 patients receiving eculizumab in addition to standard treatment (study NCT01275287).

In anticipation of novel treatments, drugs currently used to induce remission in AAV are summarized in Table 2 and include corticosteroids, CyP, MTX, MMF, Rituximab and plasmapheresis.

\section{Maintenance of remission}

The majority of patients with AAV can achieve remission within the first 6 months of treatment. However, if no other care is undertaken over half of the patients may have a relapse within the first 2 years following remission (De Groot et al. 2005). Relapses in AAV were associated with subsequent progression to end-stage renal disease (Hogan et al. 2005). Moreover, the number of relapses for an individual patient was a strong predictor of damage during follow-up, as measured by the Vasculitis Damage Index (Koldingsnes \& Nossent 2002). Therefore maintenance, once remission is achieved, is essential for the long term outcome of patients with AAV.

$\mathrm{CyP}$ as oral $\left(1.5 \mathrm{mg} / \mathrm{kg}\right.$ per day) or infusion regimen $\left(0.75 / \mathrm{m}^{2}\right.$, effusion every 3 months) was initially the standard regimen to maintain remission (Hoffman et al. 1992). Because of the serious adverse events related to long term exposure to $\mathrm{CyP}$ less toxic drugs have been proposed such as azathioprine, methotrexate, leflunomide or MMF

The CYCAZAREM study by EUVAS randomly assigned 144 patients with AAV (who achieved remission with oral $\mathrm{CyP}$ and prednisolone) to receive either azathioprine $(2 \mathrm{mg} / \mathrm{kg}$ per day; $n=71)$ or CyP $(1.5 \mathrm{mg} / \mathrm{kg}$ per day; $n=73$ ) (Jayne et al. 2003). Both treatment groups continued to receive prednisolone ( $7.5 \mathrm{mg}$ per day). At 18 months of follow-up, relapses had occurred in $15.5 \%$ and $13.7 \%$ of patients in the azathioprine and CyP group, respectively, suggesting that azathioprine is as effective as $\mathrm{CyP}$ for maintaining remission in AAV. Adverse events were comparable between the two treatment groups.

In a RCT by the French Vasculitis Study Group, 126 patients with WG or MPA following induction therapy, were randomly assigned to receive either oral azathioprine $(2 \mathrm{mg} / \mathrm{kg}$ per day; $n=63)$ or methotrexate $(0.3 \mathrm{mg} / \mathrm{kg}$ per week, progressively increased to $25 \mathrm{mg}$ per week; $n=63$ ) for 12 months. No significant difference was found between the two groups in terms of relapse-free survival and toxicity at a follow-up period of $29 \pm 13$ months (Pagnoux et al. 2008).

In another RCT, 54 patients with WG (who achieved remission after treatment with cyclophosphamide and prednisolone) were randomly assigned oral leflunomide (30 mg per 
day) or oral methotrexate (starting with $7.5 \mathrm{mg}$ per week and reaching $20 \mathrm{mg}$ per week after 8 weeks) for 2 years (Metzler et al. 2007). Leflunomide was more effective in preventing relapses than oral methotrexate (6 versus 13 relapses, respectively), but was associated with a higher rate of adverse events. However, this study was underpowered; it was initially designed for 154 patients but only 54 were enrolled.

The potential benefit of MMF treatment for maintenance of remission in AAV has been demonstrated in preliminary uncontrolled studies (Silva et al. 2010). On the basis of these studies, an RCT by EUVAS, termed IMPROVE, comparing MMF with azathioprine for maintenance of remission in renal vasculitis, has been carried out (Hiemstra et al. 2010). Among 156 patients treated either with AZA (starting at $2 \mathrm{mg} / \mathrm{kg} / \mathrm{d}$ ) or MMF (starting at $2000 \mathrm{mg} / \mathrm{d}$ ) following induction of remission with CyP and prednisolone, patients on MMF experienced more relapses compared to AZA group.

Some observational studies provide preliminary data regarding the efficacy of other regimens to maintain remission in patients with AAV. Rituximab appears to be beneficial (Stasi et al. 2006; Rhee et al. 2010). A large RCT currently evaluates the efficacy of rituximab in comparison to AZA (MAINRITSAN , Study NCT00748644). On the contrary, addition of intravenous immunoglobulin (IVIg) to standard maintenance treatment (AZA plus prednisone) does not prevent relapses (Fortin et al. 2009).

In overall, treatment with low-dose prednisolone plus AZA $(2 \mathrm{mg} / \mathrm{Kg} /$ day until 12 months then $1.5 \mathrm{mg} / \mathrm{Kg} /$ day) (Jayne et al. 2003; Pagnoux et al. 2008), or MTX (20-25 mg/week) (Pagnoux et al. 2008) is currently the preferred approach for maintenance of remission in AAV. The duration of maintenance is not known but should be $>24$ months (Lapraik et al. 2007) (Table 3).

\begin{tabular}{|l|l|l|}
\hline $\begin{array}{l}\text { Drug } \\
\text { Prednisolone }\end{array}$ & $\begin{array}{l}\text { Dosage } \\
\text { Starting from } 15 \\
\text { mg/day at } 3 \text { months } \\
\text { tapered to } 7.5 \mathrm{mg} / \text { day } \\
\text { at } 12 \mathrm{months}\end{array}$ & $\begin{array}{l}\text { Comments } \\
\text { Alternate-day schemes have also been } \\
\text { applied to minimize side effects. Should } \\
\text { probably be avoided in generalized or } \\
\text { severe forms of the disease }\end{array}$ \\
\hline $\begin{array}{l}\text { Cyclophosphamide } \\
\text { IV pulse }\end{array}$ & $\begin{array}{l}0.75 \mathrm{mg} / \mathrm{m}^{2} \text { every } 3 \\
\text { months }\end{array}$ & $\begin{array}{l}\text { Oral cyclophosphamide }(1.5 \\
\mathrm{mg} / \mathrm{Kg} / \text { day) might be used adjusted to } \\
\text { keep WBC }>3,000 / \mu \mathrm{L} \text { in patients who } \\
\text { experience frequent relapses }\end{array}$ \\
\hline Azathioprine & $\begin{array}{l}2 \mathrm{mg} / \mathrm{kg} / \text { day for } 12 \\
\text { months then } 1.5 \\
\mathrm{mg} / \mathrm{kg} / \text { day }\end{array}$ & $\begin{array}{l}\text { Currently the gold standard for } \\
\text { maintenance of remission }\end{array}$ \\
\hline Methotrexate & $\begin{array}{l}\text { Starting dose } 0.3 / \mathrm{kg} \\
\text { per week, increased to } \\
25 \mathrm{mg} \text { per week }\end{array}$ & $\begin{array}{l}\text { At high doses is a good alternative to } \\
\text { Azathioprine }\end{array}$ \\
\hline $\begin{array}{l}375 \mathrm{mg} / \mathrm{m}^{2} \text { every } 6 \\
\text { months }\end{array}$ & $\begin{array}{l}\text { Waits to be compared with } \\
\text { Azathiprione. Should be considered in } \\
\text { patients where AZA or MTX is either } \\
\text { contraindicated or ineffective. }\end{array}$ \\
\hline Rituximab IV & &
\end{tabular}

Table 3. Maintenance of remission in ANCA-associated vasculitis 


\section{Relapse}

Symptoms and signs of apparent AAV relapse, especially in patients on immunosuppression, should be differentiated from infections and malignancies. Relapse can be treated with oral or IV pulses of CyP plus prednisolone $(60 \mathrm{mg} /$ day) (Wegener's G.E.T.W. 2005). Patients intolerant to CyP can receive MMF (Stassen et al. 2007) or rituximab. IVIg (added to maintenance treatment) can achieve remission (Martinez et al. 2008) and it is particularly useful until infection is ruled out.

\section{Refractory disease}

Refractory disease refers to patients who experience progressive disease despite conventional treatment.

Patients with refractory disease should be treated in specialized centers. Rituximab has been successful in CyP-refractory disease in observational studies (Smith et al. 2006; Keogh et al. 2006; Jones et al. 2009; Keogh et al. 2005). Deoxyspergualin $(0.5 \mathrm{mg} / \mathrm{Kg} /$ day subcutaneously in 6 cycles of 21 days with 7-day intervals), an antiproliferative agent licensed in Japan for acute renal transplant rejection, showed promise in phase II study (Flossmann et al. 2009). Infliximab was beneficial in refractory disease in observational studies (Josselin et al. 2008) but when added to standard induction treatment did not make any difference (Morgan et al. 2010).

\section{Special issues}

\subsection{End stage renal disease (ESRD) and renal transplantation}

Relapse of ANCA-associated vasculitis is significantly less frequent (0.08 episodes/personyear) in ESRD patients compared with patients with preserved renal function $(0.16-0.20$ episodes/person-year), but infection, an important cause of death is almost double in frequency in ESRD (Lionaki et al. 2009). Therefore, immunosuppression in patients with ESRD may be limited to patients with active vasculitis.

Patients with ESRD can receive renal transplants. The overall survival of renal transplants is $90 \%$ at 5 years (Gera et al. 2007), and $70 \%$ at 10 years (Little et al. 2009). In one study, risk factors for renal transplant rejection was transplantation $<12$ months postvasculitis remission (Little et al. 2009). Therefore, renal transplantation should be considered in patients with ESRD with sustained remission of vasculitis.

\subsection{Subglottic stenosis}

Patients with active disease receive aggressive treatment with prednisolone and $\mathrm{CyP}$, and tracheostomy, if needed. Rituximab may also be used in case of $\mathrm{CyP}$ inadequate response. In inactive disease, intralesional costicosteroid with dilatation is generally effective (Hernandez-Rodriguez et al. 2010).

\subsection{Orbital mass}

Aggressive treatment with steroids and $\mathrm{CyP}$ is the standard of care. Rituximab is effective in refractory cases 


\subsection{Precautions}

CyP dose should be adjusted for renal function and age.

There should be vigilance for side effects of drugs used (CyP, rituximab, MTX, IVIg, plasmapheresis). Patients should be checked for tuberculosis with chest $\mathrm{x}$-rays and PPD skin test, and patients with latent tuberculosis should receive prophylaxis with isoniazid plus vitamin B6. Patients on IV pulse $\mathrm{CyP}$, receive antiemetic drug (ondesarton) immediately prior to and 8 hours after the CyP pulse. On the day of IV CyP pulse, patients receive oral or IV hydration with 2-3 liters of fluid. They also receive IV 2-mercaptoethanesulfonate (mesna) (20\% of CyP dose) immediately before and at 2, 4 and 8 hours after the CyP pulse to reduce irritation of urinary bladder. The dose of next IV CyP pulse is adjusted to keep nadir WBC (12-14 days after the IV pulse) $>3,000 / \mu \mathrm{L}$. The rate of leucopenia, infections, and gonadal toxicity is reduced in the IV pulse CyP compared to oral CyP regimen (De Groot et al. 2009; Haubitz \& Schellong 1998). Oral mesna is also beneficial for patients on oral CyP.

According to a recent study ever-tobacco smoking and previous episode of hemorrhagic cystitis were strong predictors for the development of cancer in the urinary tract. Thus patients with these characteristics need close surveillance.

All patients receiving $\mathrm{CyP}$ are advised to take prophylaxis against Pneumocystis jiroveci with trimethoprime/sulphamethoxazole (800/160 mg thrice weekly). This may also prevent relapses in patients with respiratory involvement (Zycinska et al. 2009).

Gonadal failure is a common side effect in patients treated with $\mathrm{CyP}$, where the risk increases in parallel with the increase of the cumulative dose received. No standard care to preserve gonadal function has been proposed for patients with AAV under CyP. Similar issues encountered in patients with systemic lupus erythematosus (SLE) have been addressed. For women with SLE two protocols exist: administration of leuprolide acetate with or without transdermal estrogen and depo-progesterone for contraception. Leuprolide should be administered 10-14 days prior to each CyP infusion. In men with SLE, administration of intramuscular monthly injections of testosterone has been proposed. Analogous approaches should probably be established for young patients with AAV at risk.

Patients on immunosuppression should not be vaccinated with live attenuated vaccines. They can and should be vaccinated with dead pathogens. Patients with WG exhibit adequate antibody (Holvast et al. 2009) and cell-mediated (Holvast ARD2010) immune response to influenza vaccines (Holvast et al. 2010).

\section{Conclusion}

The treatment of ANCA-associated vasculitis (AAV) has evolved over the years from treatment of individual members of the group i.e Wegener granulomatosis(WG), ChurgStrauss syndrome (CSS), microscopic polyangiitis (MPA), to unified treatment. For years, treatment of WG was corticosteroids plus oral cyclophosphamide (CyP), which was effective but had a high frequency of severe adverse effects (Hoffman AIM1992). To reduce the adverse effects of $\mathrm{CyP}$, notably, bone marrow suppression and infections, hemorrhagic cystitis, gonadal toxicity, and tumors, other regimens were sought. So, intense immunosuppression with $\mathrm{CyP}$ is used only for induction of remission, and then remission is maintained with drugs with fewer side effects, such as azathioprine (AZA) and 
methotrexate (MTX). In addition, the regimen for the induction of remission is individualized according to disease severity.

\section{References}

Adu, D., Pall, A., Luqmani, R.A., Richards, N.T., Howie, A.J., Emery, P., Michael, J., Savage, C.O. \& Bacon, P.A. (1997) Controlled trial of pulse versus continuous prednisolone and cyclophosphamide in the treatment of systemic vasculitis. QJM: monthly journal of the Association of Physicians, 90, pp. 401.

Booth, A., Harper, L., Hammad, T., Bacon, P., Griffith, M., Levy, J., Savage, C., Pusey, C. \& Jayne, D. (2004) Prospective study of TNFalpha blockade with infliximab in antineutrophil cytoplasmic antibody-associated systemic vasculitis. Journal of the American Society of Nephrology: JASN, 15, pp. 717.

De Groot, K., Harper, L., Jayne, D.R., Flores, S.L.F., Gregorini, G., Gross, W.L., Luqmani, R., Pusey, C.D., Rasmussen, N. \& Sinico, R.A. (2009) Pulse versus daily oral cyclophosphamide for induction of remission in antineutrophil cytoplasmic antibody-associated vasculitis: a randomized trial. Annals of internal medicine, 150, pp. 670 .

De Groot, K., Rasmussen, N., Bacon, P.A., Tervaert, J.W., Feighery, C., Gregorini, G., Gross, W.L., Luqmani, R. \& Jayne, D.R. (2005) Randomized trial of cyclophosphamide versus methotrexate for induction of remission in early systemic antineutrophil cytoplasmic antibody-associated vasculitis. Arthritis and rheumatism, 52, pp. 2461.

De Lind, V.W.R.A., Hauer, H.A., Wolterbeek, R., Jayne, D.R., Gaskin, G. \& RASMUSSEN, N. (2007) Chances of renal recovery for dialysis-dependent ANCA-associated glomerulonephritis. Journal of the American Society of Nephrology: JASN, 18, pp. 2189.

Flossmann, O., Baslund, B., Bruchfeld, A., Cohen, T.J.W., Hall, C., Heinzel, P., Hellmich, B., Luqmani, R.A., Nemoto, K. \& Tesar, V. (2009) Deoxyspergualin in relapsing and refractory Wegener's granulomatosis. Annals of the rheumatic diseases, 68, pp. 1125.

Fortin, P.M., Tejani, A.M., Bassett, K. \& Musini, V.M. (2009) Intravenous immunoglobulin as adjuvant therapy for Wegener's granulomatosis. Cochrane database of systematic reviews (Online), pp. CD007057.

Gera, M., Griffin, M.D., Specks, U., Leung, N., Stegall, M.D. \& Fervenza, F.C. (2007) Recurrence of ANCA-associated vasculitis following renal transplantation in the modern era of immunosupression. Kidney international, 71, pp. 1296.

Guillevin, L., Cordier, J.F., Lhote, F., Cohen, P., Jarrousse, B., Royer, I., Lesavre, P., Jacquot, C., Bindi, P. \& Bielefeld, P. (1997) A prospective, multicenter, randomized trial comparing steroids and pulse cyclophosphamide versus steroids and oral cyclophosphamide in the treatment of generalized Wegener's granulomatosis. Arthritis and rheumatism, 40, pp. 2187.

Haubitz, M. \& Schellong, S. (1998) Intravenous pulse administration of cyclophosphamide versus daily oral treatment in patients with antineutrophil cytoplasmic antibody- 
associated vasculitis and renal involvement: a prospective, randomized study. Arthritis and rheumatism, 41, pp. 1835.

Hernandez-Rodriguez, J., Hoffman, G.S. \& Koening, C.L. (2010) Surgical interventions and local therapy for Wegener's granulomatosis. Current opinion in rheumatology, 22, pp. 29.

Hiemstra, T.F., Walsh, M., Mahr, A., Savage, C.O., DE Groot, K., Harper, L., Hauser, T., Neumann, I., Tesar, V. \& Wissing, K.M. (2010) Mycophenolate Mofetil vs Azathioprine for Remission Maintenance in Antineutrophil Cytoplasmic AntibodyAssociated Vasculitis: A Randomized Controlled Trial. JAMA: the journal of the American Medical Association.

Hoffman, G.S., Kerr, G.S., Leavitt, R.Y., Hallahan, C.W., Lebovics, R.S., Travis, W.D., Rottem, M. \& Fauci, A.S. (1992) Wegener granulomatosis: an analysis of 158 patients. Annals of internal medicine, 116, pp. 488.

Hogan, S.L., Falk, R.J., Chin, H., Cai, J., Jennette, C.E., Jennette, J.C. \& Nachman, P.H. (2005) Predictors of relapse and treatment resistance in antineutrophil cytoplasmic antibody-associated small-vessel vasculitis. Annals of internal medicine, 143, pp. 621.

Holvast, A., DE Haan, A., Van Assen, S., Stegeman, C.A., Huitema, M.G., Huckriede, A., Benne, C.A., Westra, J., Palache, A. \& Wilschut, J. (2010) Cell-mediated immune responses to influenza vaccination in Wegener's granulomatosis. Annals of the rheumatic diseases, 69, pp. 924.

Holvast, A., Stegeman, C.A., Benne, C.A., Huckriede, A., Wilschut, J.C., Palache, A.M., Kallenberg, C.G. \& Bijl, M. (2009) Wegener's granulomatosis patients show an adequate antibody response to influenza vaccination. Annals of the rheumatic diseases, 68, pp. 873.

Hu, W., Liu, C., Xie, H., Chen, H., Liu, Z. \& LI, L. (2008) Mycophenolate mofetil versus cyclophosphamide for inducing remission of ANCA vasculitis with moderate renal involvement. Nephrology, dialysis, transplantation: official publication of the European Dialysis and Transplant Association-European Renal Association, 23, pp. 1307.

Jayne, D., Rasmussen, N., Andrassy, K., Bacon, P., Tervaert, J.W., Dadonien ,J., Ekstrand, A., Gaskin, G., Gregorini, G. \& De Groot, K. (2003) A randomized trial of maintenance therapy for vasculitis associated with antineutrophil cytoplasmic autoantibodies. The New England journal of medicine, 349, pp. 36.

Jayne, D.R., Gaskin, G., Rasmussen, N., Abramowicz, D., Ferrario, F., Guillevin, L., Mirapeix, E., Savage, C.O., Sinico, R.A. \& Stegeman, C.A. (2007) Randomized trial of plasma exchange or high-dosage methylprednisolone as adjunctive therapy for severe renal vasculitis. Journal of the American Society of Nephrology: JASN, 18, pp. 2180.

Jayne, D.R. \& Rasmussen, N. (1997) Treatment of antineutrophil cytoplasm autoantibodyassociated systemic vasculitis: initiatives of the European Community Systemic Vasculitis Clinical Trials Study Group. Journal of the American Society of Nephrology: JASN, 72, pp. 737.

Jones, R.B., Cohen, T.J.W., Hauser, T., Luqmani, R., Morgan, M.D., Peh, C.A., Savage, C.O., Segelmark, M., Tesar, V. \& Van Paassen, P. (2010) Rituximab versus 
Cyclophosphamide in ANCA-Associated Renal Vasculitis. The New England journal of medicine, 363, pp. 211.

Jones, R.B., Ferraro, A.J., Chaudhry, A.N., Brogan, P., Salama, A.D., Smith, K.G., Savage, C.O. \& Jayne, D.R. (2009) A multicenter survey of rituximab therapy for refractory antineutrophil cytoplasmic antibody-associated vasculitis. Arthritis and rheumatism, 60, pp. 2156.

Josselin, L., Mahr, A., Cohen, P., Pagnoux, C., Guaydier-Souqui申res, G., Hayem, G., JobDeslandre, C., Liferman, F., Pourrat, J. \& Guillevin, L. (2008) Infliximab efficacy and safety against refractory systemic necrotising vasculitides: long-term follow-up of 15 patients. Annals of the rheumatic diseases, 67, pp. 1343.

Keogh, K.A., Wylam, M.E., Stone, J.H. \& Specks, U. (2005) Induction of remission by B lymphocyte depletion in eleven patients with refractory antineutrophil cytoplasmic antibody-associated vasculitis. Arthritis and rheumatism, 52, pp. 262.

Keogh, K.A., Ytterberg, S.R., Fervenza, F.C., Carlson, K.A., Schroeder, D.R. \& Specks, U. (2006) Rituximab for Refractory Wegener's Granulomatosis: Report of a Prospective, Open-Label Pilot Trial. American Journal of Respiratory and Critical Care Medicine, 173, pp. 180.

Koldingsnes, W. \& Nossent, H. (2002) Predictors of survival and organ damage in Wegener's granulomatosis. Rheumatology (Oxford, England), 41, pp. 572.

Lapraik, C., Watts, R., Bacon, P., Carruthers, D., Chakravarty, K., D'cruz, D., Guillevin, L., Harper, L., Jayne, D. \& Luqmani, R. (2007) BSR and BHPR guidelines for the management of adults with ANCA associated vasculitis. Rheumatology (Oxford, England), 46, pp. 1615.

Lionaki, S., Hogan, S.L., Jennette, C.E., Hu, Y., Hamra, J.B., Jennette, J.C., Falk, R.J. \& Nachman, P.H. (2009) The clinical course of ANCA small-vessel vasculitis on chronic dialysis. Kidney international, 76, pp. 644.

Little, M.A., Hassan, B., Jacques, S., Game, D., Salisbury, E., Courtney, A.E., Brown, C., Salama, A.D. \& Harper, L. (2009) Renal transplantation in systemic vasculitis: when is it safe? Nephrology, dialysis, transplantation: official publication of the European Dialysis and Transplant Association-European Renal Association, 24, pp. 3219.

Martinez, V., Cohen, P., Pagnoux, C., Vinzio, S., Mahr, A., Mouthon, L., Sailler, L., Delaunay, C., Sadoun, A. \& Guillevin, L. (2008) Intravenous immunoglobulins for relapses of systemic vasculitides associated with antineutrophil cytoplasmic autoantibodies: results of a multicenter, prospective, open-label study of twenty-two patients. Arthritis and rheumatism, 58, pp. 308.

Metzler, C., Miehle, N., Manger, K., Iking-Konert, C., DE Groot, K., Hellmich, B., Gross, W.L. \& Reinhold-Keller, E. (2007) Elevated relapse rate under oral methotrexate versus leflunomide for maintenance of remission in Wegener's granulomatosis. Rheumatology (Oxford, England), 46, pp. 1087.

Morgan, M.D., Drayson, M.T., Savage, C.O. \& Harper, L. (2010) Addition of Infliximab to Standard Therapy for ANCA-Associated Vasculitis. Nephron.Clinical practice, 117, pp. c89.

Mukhtyar, C., Guillevin, L., Cid, M.C., Dasgupta, B., DE Groot, K., Gross, W., Hauser, T., Hellmich, B., Jayne, D. \& Kallenberg, C.G. (2009) Eular recommendations for the 
management of primary small and medium vessel vasculitis. Annals of the rheumatic diseases, 68, pp. 310.

Pagnoux, C., Mahr, A., Hamidou, M.A., Boffa, J.J., Ruivard, M., Ducroix, J.P., Kyndt, X., Lifermann, F., Papo, T. \& Lambert, M. (2008) Azathioprine or methotrexate maintenance for ANCA-associated vasculitis. The New England journal of medicine, 359, pp. 2790.

Rhee, E.P., Laliberte, K.A. \& Niles, J.L. (2010) Rituximab as Maintenance Therapy for AntiNeutrophil Cytoplasmic Antibody-Associated Vasculitis. Clinical journal of the American Society of Nephrology: CJASN.

Rutgers, A., Slot, M., Van Paassen, P., Van Breda, V.P., Heeringa, P. \& Tervaert, J.W. (2005) Coexistence of anti-glomerular basement membrane antibodies and myeloperoxidase-ANCAs in crescentic glomerulonephritis. American journal of kidney diseases: the official journal of the National Kidney Foundation, 46, pp. 253.

Silva, F., Specks, U., Kalra, S., Hogan, M.C., Leung, N., Sethi, S. \& Fervenza, F.C. (2010) Mycophenolate mofetil for induction and maintenance of remission in microscopic polyangiitis with mild to moderate renal involvement--a prospective, open-label pilot trial. Clinical journal of the American Society of Nephrology: CJASN, 5, pp. 445.

Smith, K.G., Jones, R.B., Burns, S.M. \& Jayne, D.R. (2006) Long-term comparison of rituximab treatment for refractory systemic lupus erythematosus and vasculitis: Remission, relapse, and re-treatment. Arthritis and rheumatism, 54, pp. 2970.

Stasi, R., Stipa, E., Del Poeta, G., Amadori, S., Newland, A.C. \& Provan, D. (2006) Long-term observation of patients with anti-neutrophil cytoplasmic antibody-associated vasculitis treated with rituximab. Rheumatology (Oxford, England), 45, pp. 1432.

Stassen, P.M., Tervaert, J.W.C. \& Stegeman, C.A. (2007) Induction of remission in active anti neutrophil cytoplasmic antibody associated vasculitis with mycophenolate mofetil in patients who cannot be treated with cyclophosphamide. Annals of the rheumatic diseases, 66, pp. 798.

Stone, J.H., Holbrook, J.T., Marriott, M.A., Tibbs, A.K., Sejismundo, L.P., Min, Y.I., SPECKS, U., MERKEL, P.A., SPIERA, R. \& DAVIS, J.C. (2006) Solid malignancies among patients in the Wegener's Granulomatosis Etanercept Trial. Arthritis and rheumatism, 54, pp. 1608.

Stone, J.H., Merkel, P.A., Spiera, R., Seo, P., Langford, C.A., Hoffman, G.S., Kallenberg, C.G., ST Clair, E.W., Turkiewicz, A. \& Tchao, N.K. (2010) Rituximab versus Cyclophosphamide for ANCA-Associated Vasculitis. The New England journal of medicine, 363, pp. 221.

Wegener's G.E.T.W. (2005) Etanercept plus standard therapy for Wegener's granulomatosis. The New England journal of medicine, 352, pp. 351.

Xiao, H., Heeringa, P., Hu, P., Liu, Z., Zhao, M., Aratani, Y., Maeda, N., Falk, R.J. \& JENNETTE, J.C. (2002) Antineutrophil cytoplasmic autoantibodies specific for myeloperoxidase cause glomerulonephritis and vasculitis in mice. The Journal of clinical investigation, 110, pp. 955. 
Zycinska, K., Wardyn, K.A., Zielonka, T.M., Krupa, R. \& Lukas, W. (2009) Co-trimoxazole and prevention of relapses of PR3-ANCA positive vasculitis with pulmonary involvement. European journal of medical research, 14, pp. 265. 


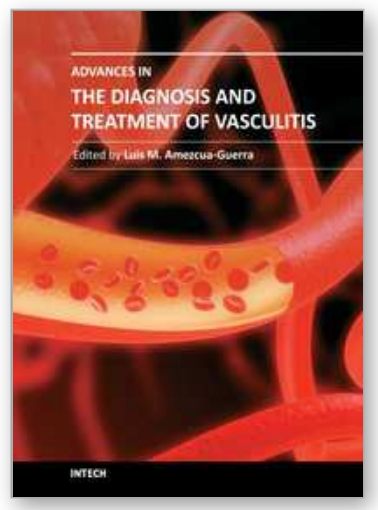

\author{
Advances in the Diagnosis and Treatment of Vasculitis \\ Edited by Dr. Luis M Amezcua-Guerra
}

ISBN 978-953-307-786-4

Hard cover, 366 pages

Publisher InTech

Published online 09, November, 2011

Published in print edition November, 2011

This book represents the culmination of the efforts of a group of outstanding experts in vasculitis from all over the world, who have endeavored to draw themselves into this volume by keeping both the text and the accompanying figures and tables lucid and memorable. The book provides practical information about the screening approach to vasculitis by laboratory analysis, histopathology and advanced image techniques, current standard treatment along with new and more specific interventions including biologic agents, reparative surgery and experimental therapies, as well as miscellaneous issues such as the extra temporal manifestations of "temporal arteritis" or the diffuse alveolar hemorrhage syndrome. The editor and each of the authors invite you to share this journey by one of the most exciting fields of the medicine, the world of Vasculitis.

\title{
How to reference
}

In order to correctly reference this scholarly work, feel free to copy and paste the following:

Christina G. Katsiari and Lazaros Sakkas (2011). Treatment of ANCA - Associated Vasculitis, Advances in the Diagnosis and Treatment of Vasculitis, Dr. Luis M Amezcua-Guerra (Ed.), ISBN: 978-953-307-786-4, InTech, Available from: http://www.intechopen.com/books/advances-in-the-diagnosis-and-treatment-ofvasculitis/treatment-of-anca-associated-vasculitis

\section{INTECH}

open science | open minds

\author{
InTech Europe \\ University Campus STeP Ri \\ Slavka Krautzeka 83/A \\ 51000 Rijeka, Croatia \\ Phone: +385 (51) 770447 \\ Fax: +385 (51) 686166 \\ www.intechopen.com
}

\author{
InTech China \\ Unit 405, Office Block, Hotel Equatorial Shanghai \\ No.65, Yan An Road (West), Shanghai, 200040, China \\ 中国上海市延安西路65号上海国际贵都大饭店办公楼405单元 \\ Phone: +86-21-62489820 \\ Fax: +86-21-62489821
}


(C) 2011 The Author(s). Licensee IntechOpen. This is an open access article distributed under the terms of the Creative Commons Attribution 3.0 License, which permits unrestricted use, distribution, and reproduction in any medium, provided the original work is properly cited. 